\title{
Hybrid Institutionas An Enabling Factor of Innovation System: A Case Study of BUM Desa "Sejahtera" Bleberan Village, Gunung Kidul
}

\author{
Sumarjono*, Fatih Gama Abisono, Parwoto, Fajar Sidik and Widati \\ Sekolah Tinggi Pembangunan Masyarakat Desa “APMD” Yogyakarta, Indonesia \\ "massumar21@gmail.com, fatih.abisono@gmail.com
}

\begin{abstract}
This study aims to find the institutional power of BUM Desa as a hybrid institution for the growth of innovation in local economic development in the Bleberan Village, Gunung Kidul. Previous studies of economic institutional links and innovation show that innovation factors are key to strengthening economic institutions. The difference from previous studies is that economic institutions are the determining factor in building an innovation ecosystem. The hybrid institution design inherent in BUM Desa presents several opportunities in the form of institutional excellence that can be utilized to overcome the limitations of strengthening the village economy. The findings of this study are in the case of BUM Desa "Sejahtera" the prerequisites of the hybrid institution format have not been fulfilled due to the weak capacity to institutionalize the rules of the game that bind the perpetrators and instead drag the perpetrators into involvement in conflicts that are not managed. As a result, BUM Desa "Sejahtera" failed in becoming an incubator for the growth of village innovation. Citizen innovation that initially grew did not develop because it was not well captured by BUM Desa. This study is a qualitative study using an instrumental case study method that is oriented towards enriching the theoretical treasure of economic institutions.
\end{abstract}

Keyword: BUM Desa, Hybrid institution, Innovation ecosystem

\section{Introduction}

The issuance of the Village Law has opened the space for recognition of local authority for the village in developing the potential of its resources through the formation of the Village BUM. Within this framework, BUM Desa is intended as a forum for village businesses, with a spirit of independence, togetherness, and cooperation between the village government and the community in developing local assets to provide services to citizens and increase the economic income of the community and village [1]. The impact, there was a boom in the establishment of BUM Desa. Within two years, the number of BUM Desa increased by 14 times from 1,022 units in 2014 to 14,686 units in 2016 [2].

The mandate as an institution for village economic institutions has placed BUM Desa as a central actor for village independence, which has led to several arguments that the design of BUM Desa as a hybrid institution. Firstly, BUM Desa was born from state regulations as well as local initiatives. BUM Desa has an opportunity whose presence is guaranteed with a legal umbrella while providing recognition for the existence of local initiatives. Secondly, the BUM

Article history:

Received (December 21, 2019), Review Result (January 26, 2020), Accepted (April 5, 2020) 
Desa institutional is designed as a village business characterized by collective ownership. It is not only owned by the village government or the community but also belongs to the government and the village community [1] which has the consequence of integrating community-based economic empowerment with village government. Thirdly, BUM Desa is managed democratically and technocratic as seen from the use of managerialism. However, BUM Desa will not work well despite having a good managerial capacity [3]. At this point, an approach to economic democracy needs to be presented that is not only about institutionalizing village deliberations, but also accountability [1]. Fourthly, BUM Desa has the mandate to perform social services while at the same time developing local-scale economic potential. The presence of BUM Desa is expected to not only generate profits, but also the motor of economic development for the welfare of citizens which requires a balance of social and commercial functions.

This study assumes that the design of hybrid institutions inherent in BUM Desa presents some institutional advantages to overcome the limitations of strengthening the local economy. Thus, it can become an enabling factor for the birth of innovation in the village. At this point, the argument needs to be tested. Factually, BUM Desa has not yet become the choice for many villages in Indonesia. Until the end of 2016, only around 29\% had pioneered the establishment of BUM Desa. Of the $29 \%$ of villages that have pioneered the formation of BUM Desa, only $39 \%$ have BUM Desa being able to be active in productive economic activities. The $61 \%$ of BUM Desa, have only the legality of AD / ART and are only supported by insignificant equity participation [4]. The data shows that not all village economic institutions in the BUM Desa format can utilize hybrid institutions as enabling factors for innovation.

The tourism village was chosen as the case study to test the argument with several considerations. Firstly, tourism villages fulfill the regulatory aspects while because many tourism villages were born from local initiatives. The regulation of tourism villages has been regulated in Permendesa No.4 of 2015 concerning on BUM Desa. With this authority, many villages in Indonesia began to pioneer and develop tourism villages through the BUM Desa [5]. Secondly, the tourism business is echoed as an inclusive economic sector involving multifactors. The fact is that local people have just been placed as spectators in the tourism industry. Tourism must be seen as a local resource, so its management must be based on local interests and the ability to provide labor and social capital [6]. Thirdly, the type of tourism business has been named as one of the prospective creative economic sub-sectors which demands continuous innovation. This type of business requires high competitiveness that demands a touch in adding value to other factors of production.

Contextualize in this study, BUM Sejahtera Village in Bleberan Village, Gunungkidul was chosen as the location of the study because it was considered relevant to represent the contemporary issues above. In 2015, Bleberan has named the best tourism village in DIY and was able to generate billions of incomes annually. The Bleberan Village was used as a comparative study of almost all regions of Indonesia to learn to manage natural tourism villages through BUM Desa. The Bleberan Tourism Village in 2017 which was managed and developed through BUM Desa Sejahtera became one of the best tours by the Ministry of Village category of Science and Technology.

This paper is organized as follow: Section 2 presents the literature review. Section 3 describe the proposed research method. Section 4 presents the result and following by discussion. Finally, Section 5 concludes this work.

\section{The literature review}




\subsection{Previous studies}

Most studies of the village economic institutional have only been engaged in promoting success or finding factors for failure. The study of BUM Desa is still exploring the possibility of BUM Desa as an economic institutional model that is believed to be ideal. There are not many studies on BUM Desa that are oriented to test BUM Desa as a village economic institution that is in line with the interests of strengthening village independence. This study focuses on the orientation that it is important to test the institutional power of BUM Desa to strengthen the village economy by linking to BUM Desa's capacity to produce innovation. The main argument to be built is the belief that innovation is an important variable changing the economic structure of the village towards independence. However, the innovation factor is not placed as an independent variable but instead puts the BUM Desa institution as an innovation ecosystem.

The previous study focused on the failure or the success of BUM Desa which has developed a lot of village potential. The finding from Suryana et al in [10], their study was in Tabanan Bali which has developed 50 BUMs. It shows BUM Desa is considered successful in encouraging the participation of farmer groups and able to improve their economy. Whereas Babadan Village, Tulungagung was considered successful in implementing a savings and loan program for Poor Households (RTM/Rumah Tangga Miskin) in developing business through BUM Desa. Meanwhile, BUM Desa in Bleberan is considered as a model for sustainable poverty alleviation, because it can build villages with social capital in their communities [7]. Even though social capital works, in the management of tourism villages it has not been managed transparently and accountably by BUM Desa Bleberan [2].

Not only limited to success stories, but also other areas experienced obstacles. As happened in Landungsari Village, Malang, the existence of BUM Desa is following local regulations and confirmed in Village Regulations. However, all business sectors did not work so that the existence of BUM Desa was only limited to a nameplate [8]. In the Village of WarungBambu, Karawang, the existence of BUM Desa has not been able to empower the economy of its citizens [9]. In Jombang, BUM Desa is considered to contribute to Village Original Revenue but BUM Desa has not been professionally managed so it has not been able to develop business [10]. While Kushartono's study in [9] stated that, BUM Desa in Jepara has not been able to help improve the village economy due to the constraints of the type of business being run, the low human resources and the lack of community participation.

Meanwhile, the study of village economic institutions concerning innovation, only within the framework of innovation is a variable changing institutional economy. Several studies on innovative villages show that innovations that argue the factors of production both natural, human, and institutions have driven changes in village economic institutions. Study of SI on [11] changes in the marketing platform for agricultural products of Mlatiharjo Demak villagers through digital markets managed by BUM Desa concluded that the introduction of digital technology has strengthened village economic institutions. This conclusion is in line with a study conducted by Cosgrove in [12] on clean water management by BUM Tirta Kencana Village, Karangrejek, Gunung Kidul.

Other studies show the role of innovation that touches on the realm of village economic institutions. Anggraeni with her study in [13], shows that innovation in the realm of process/governance, business units /products and values is the key to success in maintaining the presence of BUM Desa Panggung Lestari amid dynamic business competition. Similarly, Payne in [14] found the use of stakeholder networks to be a key institutional innovation strategy that effectively and has been proven to advance the Pentingsari tourism village, Sleman. Then, Lisetchi's Study in [15] argues that innovation in community organizing as a key factor in the 
development of Nglanggeran Gunung Kidul Tourism Village. Similarly, it was shown by Triambodo in his study of strengthening the economic institutions of tourism villages through creative economic development strategies.

This study is different from previous studies that put the "hybrid" BUM Desa institution as an ecosystem for the development of village independence innovations that are oriented to testing the institutional power of the village economy. This study also tries to formulate a prototype for a model of strengthening village economic institutions in the BUM Desa format. Thus, this research has a new contribution to the lacunae of previous studies.

\subsection{BUM Desa as "hybrid institutions"}

BUM Desa is not only placed as a social institution or a commercial institution. However, BUM Desa is also placed as a common pool resource management agency in handling conflicts of various village stakeholders. Hardin in [16] explains in "The Tragedy of the Commons" if shared resources cannot be controlled properly it will cause problems. Hardin in [16] proposes a thesis where a tragedy occurs when each individual freely maximizes openly limited resources for personal interests that encourage competition between one another. Privatization of state rules regarding restrictions and prohibitions, taxation, and agreements with users (users) are suggestions from Hardin to avoid tragedy [16]. Meanwhile, Ostrom in [17] has a different view, in the use of "Common Pool Resources" there will be no tragedy when managed through community organizations (communal governance) in institutions that are formed collectively and can self-regulate or are called self-governing [17]

Mediating these two views, basically managing common-pool resource is a discourse on conflict management between individual-community-state. In the discourse above, institutional regulation is needed as a solution to overcome the problem of conflict that occurs mainly in the community, as Bishop explained that: "With the institutional regulation it implies, is capable of satisfactory performance in the management of natural resources and institutions might be helpful in the solution of present problems of natural resources policy ". Then, Wade points out that the collective activities of a community in a social organization require the encouragement of a legal framework in their local systems by the government to be used as a guide in managing and utilizing common pool resources.

Managing common-pool resource individually, community and state are still considered ineffective when facing a conflict that occurs, it is necessary to use mixed institutions or called "hybrid institutions" [18]. German and Keeler in [18] explain that "hybrid institutions" is a mixed institution that bridges collective action and formal regulation in managing commonpool resource with various actors involved in them. In the context of "hybrid institutions", the management of common-pool resource related to; (1) common or connected interests within other forms of property (public, private), (2) the interdependencies of discrete units or forms of property (public-private-communal), and (3) other types of common goods that are not forms of natural capital, but nevertheless influence natural resource management [18]. Then, the actors involved in managing these resources are a combination of individuals, communities, and government with a binding formal regulatory approach in "hybrid institutions" [18]. So "hybrid institutions" basically build the working principle of governance of common-pool resource through a "combine self-organization with more formal regulatory approaches" [18].

In this context, this study employs "hybrid institutions" as the basis for explanations because of relevance regarding the roles, functions, and characteristics of the BUM Desa work mechanism. The concept is relevant to the position of the Village Government which has the authority to establish and develop BUM Desa as an institution of cooperation with its citizens 
in managing the common-pool resource. BUM Desa is used as a joint activity management institution that is a combination of cooperation between the village government, individuals, local communities who are formally bound by village regulations following the characteristics, and includes how detailed principles, work mechanisms in managing and developing common pool resource.

\subsection{Innovation and innovation ecosystem}

The term of innovation was first introduced by Raudino in [19] stated that the adoption of a 'new combination' which refers to new products, services, work processes, markets, policies, and systems. Innovation adds value to both the organization and the community. While the OECD in [20] defines innovation as the implementation of new products and processes that can increase market capacity. The creation of new processes and products utilizes scientific studies, technological advancements, organizational resources, and financial strength. The Oslo Manual in [20] defines innovation as "the implementation of a product (in the form of goods or services), processes, marketing methods, or new organizational methods that have been significantly improvised".

Furthermore, the definition of innovation involves the development and implementation of something new, while the term 'new' explained by Moorman in [21] does not mean original but rather novelty. Through innovation, one can add value to the company but also stakeholders and society. The scope of innovation, moves from the development and implementation of new ideas that have an impact on theory, practice, products, or lower scale, namely improvement of daily work processes and work design. Therefore, innovation research can be carried out in three levels, such as individual, group, and organizational level innovation.

Also, because this study aims to explore the concept of an innovation ecosystem. As with natural ecosystems, there are supporting elements and balanced interactions between elements. The absence of one element would disrupt the balance of the ecosystem. In the innovation ecosystem, there are elements needed: leadership, education, ethical and work ethic systems, socio-cultural systems, innovation policies, and funding that all work to support the development of innovation. Innovation will be created when there is an interaction that drives this innovation ecosystem into a harmonious and productive system.

This interaction is often described in an innovation model called "Triple Helix". Among the various knowledge-based innovation models, the triple helix relationship model provides a framework that facilitates knowledge network analysis and interaction in the innovation process. Traditionally sees innovation as the result of a collaborative network between A (academics) B (business) - G (government) where the academic world acts as a provider of knowledge, business as a locus of production becomes a beneficiary knowledge, while the government is tasked as a facilitator that conditions the synergistic interaction between suppliers and users of knowledge. Knowledge in the hands of academics is transformed into commercial products thanks to the utilization by industry and stimulated by government policy support which in turn boosts productivity through the creation of high value-added products. The triple helix interlock is the key to sustainable economic growth supported by innovation. The intertwining of the three produces energy to boost economic growth.

However, Triple Helix does not work well in many developing countries that have not been supported by a culture of innovation. However, an innovation of product depends on the needs of the community as users of knowledge that follows social, economic and cultural changes. This resulted in an evolution between innovation products and people's tastes that led to the 
transformation of the triple helix innovation model into a new model called the quadruple helix, where the community entered as one of the driving elements of the innovation wheel.

This quadruple helix model is shown by the bottom-up phenomenon through open innovation that was established from the community outside the A-B-G scheme. Unlike the triple helix which focuses on high-tech based innovation, the characteristics of this model are user-oriented (user-oriented innovation approach). Quadruple helix focuses on innovation by utilizing existing knowledge and technology, as well as utilizing the users of knowledge itself namely the community in the innovation process. The use of this model is more in favor of small businesses because it shortens the incubation time, and minimizes costs and risks in generating innovation. The presence of open innovation in the quadruple helix scheme is beneficial in fostering an innovation ecosystem that is supported by the collaboration of various parties.

\section{Research method}

This study is not intended to find a recipe for success but rather to test on the village BUM institution. It has the aim to scrutinize whether BUM Desa has the institutional capacity in handling the various challenges that emerged. The proposed arguments are; firstly, the village is faced with the demand to build independence through strengthening the economic institutions of the village. There are still many BUM Desa that have not succeeded independently, actively, and productively. Secondly, however, the development requires the innovation-based economy. Through innovation, as an efforts to strengthen the economy find opportunities for sustainability. To answer the argument, the figure below illustrates the proposed framework:

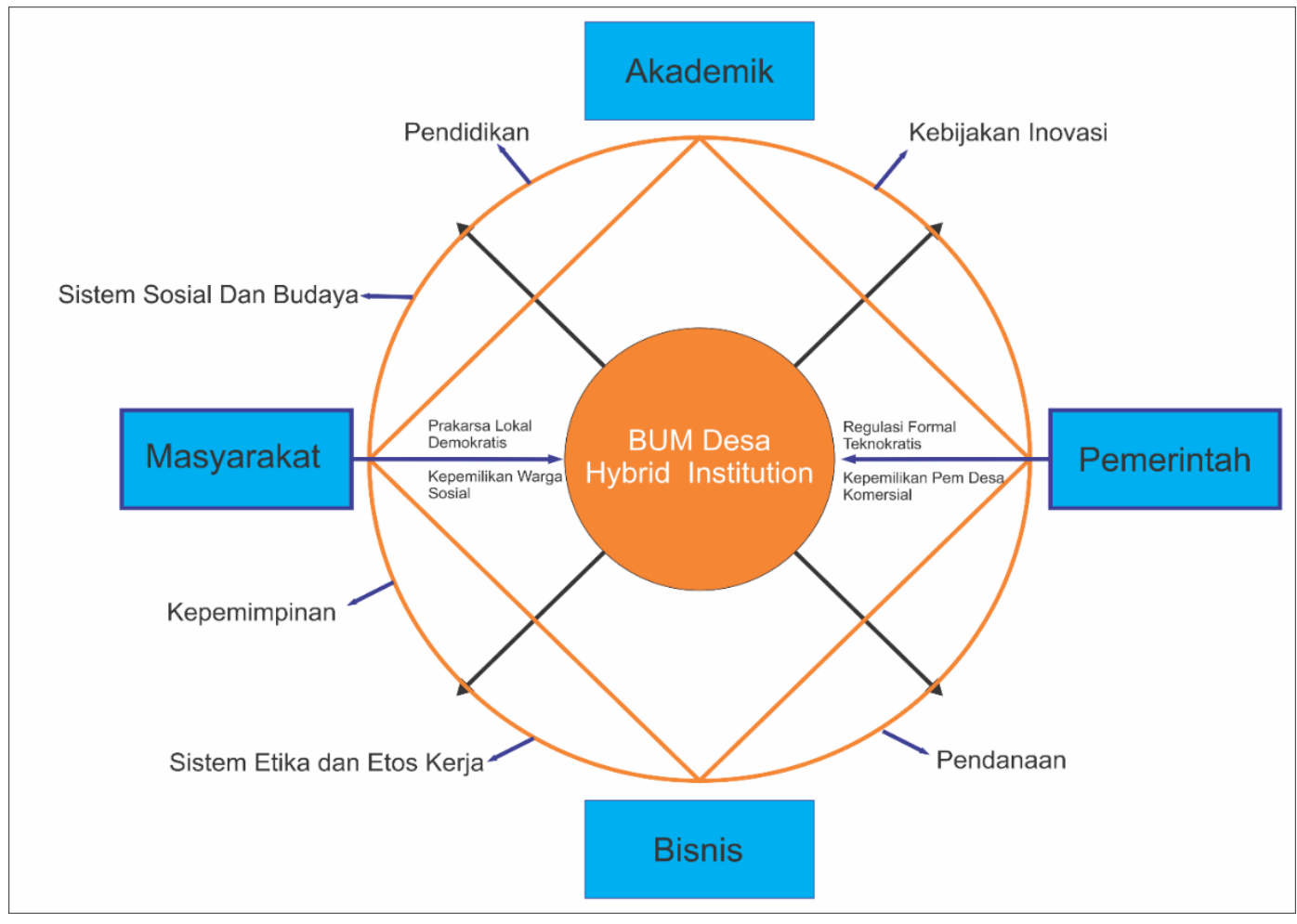

Figure 1. Research framework 
It is qualitative research with an instrumental case study strategy as the method. Case studies themselves are studies of the specificity and complexity of a case, to build an understanding of subjects in natural conditions using several data collection techniques. As Baxter in [22] states the domain of the case study method is particularization rather than generalization. These characteristics are placed in the context of the uniqueness as well as the complexity of the action under study. But generalization is not unopened in case studies. The generalization in this study is a theoretical generalization for the development of the theory. The tendency of analytical generalization is one type of case study namely the instrumental and collective types. This study places the type of instrumental case studies that are oriented to enrich theoretical treasures on economic institutions by examining the influence of BUM Desa as a hybrid institution as a village innovation ecosystem. Through the case study method, the research can be explored in more detail, in-depth, and clearly, thus it can answer the question that was proposed.

\subsection{Data sources, data collection techniques, and informants}

This study employs multi-source data evidence that is primary and secondary data. The data will be collected using in-depth interviews, observation, and documentation. Collecting primary data sources through in-depth interviews with key informants from various relevant stakeholders both the Village Government and the Village Consultative Body (BPD), BUM Managers, Village Business Actors, and Tourism community groups (POKDARWIS), community leaders, the Empowerment \& Tourism Office of Gunung Kidul district.

Secondary data include; village profiles, BUM Desa profiles, BUM Desa regulatory documents, BUM Desa accountability reports, previous research in the form of journals, and books, the article reports in the form of both national and local news. While observations were made by visiting and live in to understand the context of social dynamics. Activities that will be observed by the research team include; the situation and condition of the developed tourism village, the working room of the BUM Desa management and tourism village manager, as well as the activities carried out.

\subsection{Data analysis}

Data analysis as a series of work according to Merriam [23] in a qualitative design, including stages; data reduction, data display, and conclusion/verification. The working mechanism of the data analysis step is that after all primary and secondary data have been collected, the first step is to data reduction to focus on the research formulation. After the data is selected, the results of data analysis are presented in the form of interview quotes, tables, and figures. After the first and second phases are completed, the research team concludes from the data that has been organized as the final stage of analysis.

\section{Results and discussion}

\subsection{Socio-economic context of bleberan village}

Bleberan Village is located in Playen, Gunungkidul District. Size of the area is $16.62 \mathrm{Km} 2$ consisting of 11 hamlets, the landscape of Bleberan Village is mostly of plains. Types of agricultural land by margalite soils that tend to be barren. It is not surprising that agricultural land is only 489,217 Hectares of upland land and 493 Hectares of rainfed lowland rice field, and only 15 Hectares of rice fields with technical irrigation. Despite the barren land conditions, 
the agricultural sector is still a primary of Bleberan Village community. The average agricultural land ownership of the community only has 0.25 hectares of land for each household.

In addition to the agricultural sector, in the last 10 years, the tourism sector is growing rapidly marked by the increasing number of tourist arrivals at Sri Gethuk waterfall. In the last 5 years, tourist arrivals reached 100,000 visitors each year. The tourist attraction in Bleberan is the Oya River along with the boat with enjoying the beautiful cliffs which then end up enjoying the Srigethuk waterfall. This has an impact on the opening of new jobs and the emergence of new businesses for residents as tourism managers, traders, food stall owners, and other tourism support businesses. The tourism sector in Bleberan Village has been managed quite well through BUM Desa and is even able to contribute to village development. The concrete impact of the development of this sector can contribute not only to the Village in the form of Original Village Revenues but also to the regions.

Then other sectors such as the industry began to emerge in line with the development of tourism in Bleberan Village. Processing of agricultural products is the mainstay of business undertaken by the community to support the tourism sector. Through these various training and mentoring, community efforts have become known. In addition to the small food processing industry, other types of industries are also available, although their growth is still small, including agriculture, leathercraft, and furniture industries. The weakness of this sector is constrained by marketing that only serves the local village market. Some products such as agricultural equipment and processed food began to penetrate markets outside the village area.

The demographic data of Bleberan village, the population is 5,036 people, consisting of 2,469 men and 2,567 women. While the number of family heads in the village reached 1456, which means that the average number of members of each family head was only 3 people. The productive age of the population is 15-64 years, the non-productive age population is also large so the dependency ratio is quite high at $45,43 \%$. Meanwhile, the education level of Bleberan Village residents is still low-educated. They only attained the basic education or have not graduated from elementary school and the highest is only graduated from junior high school. There are $3.7 \%$ of Bleberan Village residents or 198 people who received higher education.

\subsection{History and business model of bumdes "Sejahtera"}

The establishment of BUM Desa in Bleberan has a unique history where it was born long before the issuance of The Village Law No.6/2014. These conditions impact the design of BUMDes in Bleberan Village not fully following the BUMDes hybrid model as intended in the Village Law. BUMDesBleberan Village was formed due to the strong local initiatives in managing its economic affairs. Several things refer to these conditions. Firstly, BUM Desa in Bleberan was established because of the encouragement of local initiatives to resolve village welfare issues and not because of the imperative of legislative regulations. Legalized by the Decree of the Village leader No.06 /2008 concerning on BUM Desa, as a form of village opportunity to utilize its productive assets. Then, Perdes No.05/2010 was established regarding the establishment of BUMDes. The amendment to the regulation is an effort to strengthen the BUM Desa legal framework which is endorsed by village regulations as a product of legislation at the village level. This shows local initiatives precede the regulations that were issued first.

Village economic strengthening through the BUMDes format it was a breakthrough because not many villages formed BUMDes as a strategic choice before the issuance of The Village Law No.6/2014. The legal basis for establishing BUM Desa referred to Regional government regulation No.32/2004 and Government Regulation No.72 /2005 concerning Villages. Then, the Government Regulation No.72 /2005 was further elaborated by Regional Regulation of 
Gunungkidul District No.5/2008 concerning the establishment of BUM Desa as a guideline in its area. Furthermore, the Central Government issued a derivative regulation as Permendagri No.39 of 2010 concerning BUM Desa.

BUM Desa "Sejahtera" Bleberan Village was established later, rather than the previous two business units. There have been two business units owned by BUM Desa, namely Clean Water Management (PAB/Pengelolaan Air Bersih) and Savings-Loans Village Economic Unit (UED$\mathrm{SP} /$ Unit EkonomiDesaSimpanPinjam). The PAB was formed in 2004 and the UED-SP was established in 2006. Both units were directly managed by the Village Government before the BUMDesa. While the establishment of a tourist unit is almost the same as BUMDesa "Sejahtera". However,tourism activities in Bleberan have been going on for a long time, before the establishment of BUMDesa, which was directly managed by community groups and not yet well managed.

The establishment of BUMDes departs from the initiative of the Village Government by considering the context of community needs. Former Head of Bleberan Village, Tri Harjono, who is also the manager of the tourism unit, told his experience when he initiated the BUMDes. Tri Harjono stated that the establishment of BUMDesa was motivated by the fact that Bleberan Village was isolated at that time, a high poverty rate marked by many residents, especially unemployed youth. Even villages are increasingly lacking in human resources because many migrate to cities. That is what drives community economic activities, including through BUMDesa. Seeing the process of establishing BUM Desa "Sejahtera" Bleberan shows that local initiatives are the key to the existence of BUM Desa. Local initiatives in Bleberan Village have become positive energy to drive changes through various innovations such as clean water services, microcredit, and the development of tourism villages. Even impressed "run first, set later".

In its development, the historical process had an impact on the formation of a typical BUMDes business model. A strong local initiative ignores the existence of BUMDes institutions. This condition has an impact on the neglect of aspects of structuring the institutional relations between the BUMDesa Management "Sejahtera" and business units. Relationships that are built produce relationships that tend to place business units seem autonomous when dealing with managers of BUM Desa. This kind of business model only places BUMDes as a formal forum for village business units. Business units seem to be running alone without involving BUMDesa management when making decisions within the management of their respective units. Practical control between BUMDes managers over business units only takes place once a year when entering the annual accountability report cycle.

This business model has advantages as well as limitations. Autonomy makes existing units more flexible in decision making related to management including strategic decisions. Existing units more easily carry out the process of adaptation in facing the demands of change and the challenges that arise, and it's easier to create innovations to meet the challenges. As a description, the development of a tourism village requires large resources including funding. The initiative of the management of the tourism unit is quite innovative, through building cooperation with the central and regional government with various program assistance that was poured into Bleberan Village and the company through the Corporate Social Responsibility (CSR) scheme to develop the Tourism Village.

In the case of the management of the tourism unit, there is an assumption that it is difficult to be intervened to make the management change. One BPD member who is also a treasurer of BUMDes, Sardjana said that when the village was still led by Tri Harjono, the management of Sri Gethuk was closed or not transparent to: "because it was not transparent, the funds obtained were never reported. This kind of business model becomes the setting for the operation of the 
innovation ecosystem in BUM Village "Sejahtera". The autonomy of business units is too strong and tends to be allowed to make business units have flexible space in development but are also vulnerable to being trapped in bad practices. This means that BUMDes does not have effective and adequate control over existing business units.

The next, BUMDesa "Sejahtera " is known by the community as a village economic institution that is given the mandate to manage and develop the economic potential of the village. However, Bleberan Village residents do not feel that they are owners of BUMDes. This situation is reflected in the community's perception that the BUMDes is part of the Village government. An example is the case of the management of Sri Gethuk waterfall, many Bleberan residents felt that the benefits were only enjoyed by a small number of residents, particularly residents of PadukuhanMenggoran 1 and Menggoran 2 where the waterfall is located. Although managed by BUMDes through the tourism business unit, in fact only residents of padukuhan have access to business opportunities at the tourist sites.

In addition to residents outside the hamlet (padukuhan), it is not permissible to participate for trading or open a small restaurant and souvenir stalls, except residents outside the hamlet who own land in a tourist location. Workers absorbed at tourist sites are only a few people from the hamlet. Also, the damaged roads towards the waterfall site as the impact of tourism activities. The situation culminated with the birth of the Bleberan Care Forum movement which rejected the exclusive right of tourism management by residents in the hamlet. The description shows that the people's protest was not addressed to BUM Desa, which should have the responsibility of carrying out the control function of the business units they support. Villagers protest were directed against a handful of tourism businesses who monopolized the management of Sri Gethuk tourism. In this context, the protest was driven by an exclusion process, thus most villagers did not feel that they enjoyed the use of the village's potential.

The Efforts to improve the management of tourism unit have been urged by the BUMDesa, but they have heeded to transparent and accountable. As several efforts to quell villagers protest, for example, were finally resolved with an agreement for the results of the management of tourism for the entire village known as the potential development fund that has been done in fours years since 2015. However, these efforts did not change the perception of the villagers that the BUMDes belonged to the village.

As a village public institution that is mandated to manage the economic potential of the village, BUMDes should be managed democratically as indicated by decision making through village deliberation(musyawarah) as a mechanism more accountable and transparent. The formation of BUMDes 'Sejahtera" had not yet been through village deliberations, but it had been formed with village regulations based on the agreement of the village leader and BPD. This does not reduce the degree of democratic BUMDes management in Bleberan.

However, democratic management is also measured by the accountability aspects of BUM Desa management. The Weak control of manager of BUM Desa "Sejahtera" has impacted on the trapping of a business unit in various practices that lead to the threat of mismanagement and corruption. Management of tourism unit in Bleberan is not transparent. Bleberan Tourism Village received many funds from various institutions. It received 65 million Rupiah through the assistance of the Tourism Village PNPM program in 2011 then continued it received 100 million Rupiah in 2012 (Mamiek, 2012). Still in the same program, in 2013 it amounted 75 million Rupiah. In the same year, Bleberan tourism village received assistance from the province with a total amount of 1.15 billion Rupiah. Bank BNI 46 also provided grants through Corporate Social Responsibility (CSR) program, with 495 million Rupiah for the development of tourism villages. 
The assistance was used for the construction of various tourism support facilities such as the construction of stalls, toilet facilities, parking areas, tourist information boards, the purchase of SAR boats and procurement of uniforms, construction of footpaths to tourist sites, construction of the public transport, waiting rooms for docks, procurement of life vests for visitors, and so forth (Report of BUMDes Sejahtera, 2013). In addition to procurement, the assistance was also used to develop the training capacity of managers and to revive the arts groups in Menggoran 1 hamlet.

But the mechanism of the aid fund is not through the BUMDes, but directly went to the leader of the tourism unit manager who is held by Tri Harjono as well as the Village leader. The grants given to the village government for the development of tourism villages did not go through the BUM Desa treasurer, as following the procedures that should be carried out where the village tourism business unit has been formally managed under the BUM Village's authority since 2010. This has been complained of by the BUMDes Treasurer "Sejahtera" , "Sardjana:" I am as the treasurer, have never received any funds into the BUM Desa account, including its report until now. I was not involved in the construction at all.

The management of the aid fund involved a small number of people, only those who were in the power circle of the village leader of Tri Harjono.Thus, the deviations that occurred could not be controlled by the villager. Accountability for the management of tourism business units was reported starting in 2013, after the public pressure who questioned tourism revenues. At that time the supervisor of BUMDes, BPD, LPMD, village officials, threatened to report the parties involved to return money or deal with the law. One BUMDes supervisor stated: "We are ready to send a letter of corruption at that time. Because there is no money, only the report". (Interview of the BUMDes Superintendent, Agus JuriantoDesa, 16/02/20 2018). The situation and conditions that have occurred have triggered internal conflicts within the organization of the BUM Desa and externally, namely from the villagers who continued to suppress or demand accountability.

In addition to the aid fund, the manager of the tourism unit also did not report the revenue accountability in 2011-2012. BUM Desa could not report the tourism unit revenue. That year, was a booming tourist visit to Bleberan which reached 120,000 people with an estimated income of around 1 billion Rupiah (Liauw, 2013). The number of visits continues to increase from year to year. However, when compared with the turnover the income obtained is not always linear with the amount of increase in visitors.

Table 1. The number of visitors and revenue of tourism business unit

\begin{tabular}{|c|c|c|}
\hline Year & Number of visitors & Revenue (Rp) \\
\hline 2013 & - & $979,459,235,00$ \\
\hline 2014 & 131.259 & $1,242.799,131,00$ \\
\hline 2015 & 139.650 & $1,912,582,082,00$ \\
\hline 2016 & 137.394 & $1.902 .082 .276,00$ \\
\hline 2017 & - & $1.816 .253 .800,00$ \\
\hline
\end{tabular}

While the technocratic dimension of managing BUM Desa "Sejahtera" has worked to improve the performance of business units. The two units such as PAB and UED-SP continue to improve their respective business management. Various efforts to improve services by PAB units continue to expand the clean water service network, carry out network maintenance, reduce the number of leaks due to water theft, and intensify billing for customers who are in arrears. While the UED-SP unit also reforms, for example by improving administration, financial management, and services in the form of providing incentives for customers who are 
orderly in making payments. All transactions in the two business units are also well recorded in various reports and accounted for in various reporting forums.

The condition portrays that the management of BUMDes "Sejahtera " has not yet run equally between the aspects of democracy and technocracy, particularly for tourism business units. The PAB and UED-SP Unit, have been managed accountability and transparency. They keep improving their business management. In contrary, the tourism business unit, as the largest contributor, has not yet fulfilled the aspects of accountability and transparency as well as improving business management.

As a hybrid institution, BUMDes is also designed to achieve the mission of social service as well as village-scale local economic development. The mission has been running in a balanced way. Business units that were formed before the BUMDes existed, namely clean water services by the PAB Unit and microcredit by the UED-SP Unit were mandated to provide social services. As is common in the area of Gunungkidul which is scarce with clean water, has made efforts of the Bleberan village to provide clean water by exploring the sources of springs in Bleberan. The pilot effort had been done since the 1990s, but it succeeds in 2004 with the establishment of the PAB. Whereas UED-SP services began in 2006 as a result of assistance from government programs. The program is based on the need for microcredit for villagers to strengthen the capital of household-scale businesses. Management is managed by the Village Government before the existence of BUMDesa.

While the function of developing the economic potential of the village has also been done by the tourism business unit. However, the tourist business unit has a multiplier effect on other business sectors such as the trade, services and industry sectors in Bleberan. Also, this sector has contributed to the largest contribution of Village Original Revenue (PADes) in the form of SHU and regional tax revenue sharing and has contributed to Regional Original Revenue (PAD).

Analyzing the explanation, it shows that Hybrid Practice does not work maximally yet. This is a finding that in the initial formation of the formation of BUM Desa itself it did not meet the Hybrid principle itself from the history of its founding.

\section{3. innovation ecosystem development by bum desa "Sejahtera"}

Analyzing the data, the contextual picture of the BUMDes format affects the BUMDes capacity in forming a conducive innovation ecosystem. In the innovation ecosystem, there are six elements needed. The first element, leadership, illustrates how BUM Desa should provide space for the perpetrators' initiatives, respond to new things, encourage the creation and manage risk after innovation. They failed to institutionalize the leadership. This happens because; firstly, the weak power of the BUM Desa management and theirdependent on higher authority. The existence of a discontinuity between the Village Government and the BUM Desa management resulted in the development of an innovation ecosystem that did not work. The role of actors in BUM Desa involved in conflicts of interest is the reason why BUM Desa is weak in making decisions. Also, BUM Desa's lack of courage to take risks is one of the causes of the lack of initiative from BUM Desa. Besides that, the commitment of BUM Desa management to create an innovation ecosystem is still minimal because of the busy schedule of each management who also works outside BUM Desa. This is similar to what was said by Tri Harjono as the leader of the tourism business unit: "There is a disconnect between the administrators of the village BUM and the Bleberan village leader. Besides, the village leader also does not dare to take risks for the development of existing potential.

The Weak leadership is also shown by the fact that BUM Desa administrators did not have the power to push for healthier management at the business unit level. The urge to change 
management in the tourism village unit has been done since 2013 but was only realized in 2018 . Despite the obstacles, an agreement finally emerged with the implementation of the canal ticket. The idea of the canal ticket arisen because of an income leak that occurred in the tourist business unit such as manipulation of the number of visitors, and the number of vehicle parking. Before this agreement was made, an innovative offer emerged to implement an automated ticketing system from one of the private university in Yogyakarta. But the offer was not welcomed well by the tour unit manager. The reluctance was driven by concerns about the decline in revenue of the tour unit manager. This was stated by one of BUM Sejahtera Village supervisors, Agus Jurianto who said: "One of the managers of the tourism unit, such as being reluctant to do so, actually asked how to make a manual ticket".

As a comparison, the PAB Business Unit has made efforts to improve management in terms of administration, finance and services thus the book closing balance presented in the Accountability Report is more transparent and accountable. The PAB Unit has also conducted a trial in using a water pump that is controlled through a remote system with information technology applications. It impacts the less operational costs incurred from the PAB unit. This is an example that in managing a healthy business unit can open up opportunities for innovation development that is in line with what was conveyed by UdiWaluya as leader of PAB Unit: "We are trying to reduce operational costs with this tool, so that the power needed to run the engine pumps can be controlled remotely".

The pattern of omission by BUM Desa tends to make business unit try their innovations. BUM Desa should facilitate thus initiatives that arise from business unit can be realized. During this time the business unit in the development of innovation is sometimes without involves BUM Desa, which causes discontinuity between the business unit and BUM Desa. As stated by Tri Harjono as Leader of the Tourism Unit: "To encourage the development of our units, we rely on loans from banks and grants from local and central government funds. And that without BUM Desa knew.

In addition to the leadership factor, the innovation ecosystem also requires the capacity of the socio-cultural environment in the form of acceptance of new things. In Bleberan, local initiatives to develop tourism potential were challenged by community leaders for fear that local social norms would erode as a result of tourism activities. In the end, those who opposed then changed the vision of Bleberan Village by adding the word "religious" behind. The vision of the Bleberan village government changed to "Development of a Productive, magnificent, Safe, Orderly and Religious Tourism Village (PINTAR). Then, the community began to be enthusiastic about the existence of the BUM Desa, this was as conveyed by Tri Harjono: "The community is not accustomed to the existence of BUM Desa, but this does not make our enthusiasm to form BUM Desa. Over time, with the presence of business units such as PAB, UED SP, and Sri Gethuk waterfall, the community began to be enthusiastic, especially since every SHU received was given potential development funds in 11 hamlets in Bleberan Village.

Besides, the low social capacity is indicated by the pessimistic attitude of the villager, to develop the existing potential. There have been local initiatives to develop the lake and megalithic site as a new tourist spot. However, due to the lack of BUM Desa facilitation and villagers support, the initiative was nevertheless realized. They tend comfortable with Sri Gethuk tourism. Even though opening a new spot can increase the number of tourists who will visit Bleberan Village. This is as stated by AgusJurianto as Superintendent of BUM Sejahtera Village: "The people here tend to be pessimistic and unsure of opening new spots. Even though the new spot can add to the appeal of Bleberan.

The low support of innovation culture is also caused by the lack of knowledge of villagers. In this case, the element of education becomes important in developing innovation. BUM Desa 
Sejahtera does not have a strong commitment to strengthening human resources that affect the less creative of villagers. Different conditions with the business unit in BUM Desa, they have a program to improve the quality of human resources by conducting a comparative study. Also, BUM Desa has not yet maximized the network of collaborative knowledge and skill with the academic community and the government.

It has made collaboration with many universities, but the results of the research have not been followed up by BUM Desa management. There was resistance to knowledge products that are considered 'disruptive' to the interests of some tourism business unit people primarily related to the idea of an automated ticket. The existence of a training program by the government has not improved the quality of existing human resources in BUM Bleberan Village. The lack of assistance after training also affects the quality of human resources. As stated by Praptono as Leader of Bleberan Village; "Indeed, in practice, we still lack initiative in efforts to improve the quality of human resources. Moreover, BUM Desa administrators often get guests from various villages in Indonesia to conduct a comparative study. "(Interview with Bleberan Village Leader, Praptono, 2/23/2018)

In the process of developing an innovative ecosystem, the next element that is the ethical system as the application of an integrity system in a code of conduct and a code of ethics in business management. In this case, it is necessary for business actors in transmitting a system of ethics and work ethic for encouraging the adaptation of the integrity system. The adaptation is running stagnant and not from the needs of the organization but because of public pressure of the FPB (Bleberan Caring Forum). As their demand for the transparent of the tourism unit such as an annual report, revenue targets, and improvement of one-stop services. So far, the public has been aware of the misappropriation of funds resulting from operations for personal gain, as stated by one of the BUM supervisors and the activator of the Bleberan Care Forum; "It was only after the demonstration that there was a slight change in the Accountability Report".

There was an improvement because the pressure affected the work ethic which improved. As happened in the tourist unit before the improvement of one-door service. Previously, tourists were bothered with payment of entrance tickets and parking, this is one of the causes of leakage of funds made by certain people. However, after there was an improvement in one-stop service and ticketing, it had an impact on improving the work ethic of the employees in the tourist unit. Because improving services will increase the incentives they receive. While outside business, it is CSR, is expected to transmit a system of ethics and work ethic that is not yet fully optimal. They only provide grants for the construction of tourist support facilities.

The next element in the process of developing an innovation ecosystem is the funding to develop the creation and utilization of the resulting innovation. But the fact is that BUM Desa tends to lack commitment in developing potential innovations in Bleberan Village. The BUM Desa management also lacks initiatives related to extracting existing funds, thus each business unit must be smart in fundraising for innovation development activities. The case of procurement of ships in tourist objects which were ideas from people in the tourist unit is not facilitated by BUM Desa. BUM Desa itself lacks initiative in the process of developing existing innovations.

The impact of the lack of control by BUM Desa on the business unit resulted in being stuck of innovative ideas. Because the business unit was asked to find other funds. In this case, the excavation of tourism unit funds became the main focus of the government and the private sector. The efforts to develop innovation also require substantial funds. Therefore many grants from government and CSR went to the tourism unit without involving BUM Desa. This was stated by Tri Harjono: "Indeed, our fundraising does not involve BUM Desa. We think that being given directly to the unit will accelerate our efforts to develop. 
In an institution is very important some policies encourage the culture of an innovation ecosystem. Factually, BUM Desa "Sejahtera" has not been able to present regulations that encourage innovation. Although government regulations are adequate, they are not used as a reference in developing innovation. In Gunung Kidul District, besides Perda No.5/2008 concerning Guidelines for Establishing Village BUMs, there is a Regulation No.5/2013 concerning the Implementation of Tourism which regulates the village tourism. This condition is in line with the statement of Bleberan Village Leader, Praptono; "For regulations related to the development of innovation, it does not yet exist, but for regulations to establish BUM Desa, it has been in existence since 2008 and we have used it until now. Indeed, the reality is not yet maximized in the application of these regulations. Sometimes it only applies to agreements between parties in the business unit. "(Interview with Bleberan Village Leader, Praptono on 02/23/2018)

Contrary to the government's claim in 2017, Bleberan Tourism Village managed and developed through BUM Desa Sejahtera became one of the best tours by the Ministry of Village category of Science and Technology. It is not true with the findings in the field. With these conditions, it is clear that not all of the six elements are met following the prerequisites for the creation of an innovation ecosystem.

\subsection{BUM Desa "Sejahtera" capacity as hybrid institution in developing innovation ecosystems}

Hybrid Institution as an ideal concept and a prerequisite for the BUM Desa. To realize the mandate as a village economic institution capable of delivering Village independence. But the practice, this concept is not easily translated operationally thus it requires a variety of instrumentation. The BUM Desa "Sejahtera" has not fulfilled the requirements as a Hybrid Institution as presented in [Table 2] below:

Table 2. Overview the circumstances BUM Desa "Sejahtera"

\begin{tabular}{|c|c|}
\hline Aspect & The existing condition \\
\hline $\begin{array}{l}\text { Local initiatives and } \\
\text { regulation }\end{array}$ & $\begin{array}{l}\text { Strong local initiatives, but not offset by the capacity to institutionalize the } \\
\text { rules of the game/agreement. It is not appropriate yet with existing regulatory } \\
\text { corridors. }\end{array}$ \\
\hline $\begin{array}{l}\text { Collective ownership of } \\
\text { villager and village } \\
\text { government }\end{array}$ & $\begin{array}{l}\text { The meaning of ownership is more focused on the village government. } \\
\text { Villagers have not yet established themselves as owners of BUM Desa }\end{array}$ \\
\hline $\begin{array}{l}\text { Democratic and Technocratic } \\
\text { Management }\end{array}$ & $\begin{array}{l}\text { There is no balance point between democratic aspects and technocratic } \\
\text { aspects in the management of BUM Desa. }\end{array}$ \\
\hline $\begin{array}{l}\text { Social Function and Economic } \\
\text { Development }\end{array}$ & $\begin{array}{l}\text { Social and economic functions have worked. But the focus is still to obtain } \\
\text { short-term economic benefits (PAD Desa). }\end{array}$ \\
\hline
\end{tabular}

In the sum of the findings, this study states that BUM Desa "Sejahtera" management practices do not meet some of the principles of hybrid institutes. As a result, BUM Desa's capacity, which is assumed to be an enabling factor for the innovation ecosystem, cannot fully work. This condition is characterized by some arguments: firstly, the leadership of BUM Desa failed to institutionalize leadership which was bound by the rules of the game that were mutually agreed upon. This is rooted in the weak enforcement of integrity in BUM Desa and the failure of the Village Government in managing conflicts of interests of the perpetrators. Secondly, BUM Desa cannot encourage the creation of adaptive social systems for innovation. This happens because there is still a distance between the BUM Desa and the villagers. They have not positioned themselves as the "owner" of BUM Desa. Thirdly, BUM Desa has not yet 
optimally utilized knowledge resources even though they have networks. This condition occurs because there is no awareness of the importance of knowledge for innovation. Fourthly, less in strengthening work ethic, it occurs when there is pressure from outside the BUM Desa, especially from villagers. Enforcement of public ethics is part of efforts to achieve democratic values marked by transparency and accountability. Fifthly, BUM Desa does not yet have a strong commitment to funding the development of innovation. Even though innovation is needed as an effort to develop the social and economic service function of the villagers. Sixthly, BUM Desa has not been able to create regulations that encourage innovation.

The portrait questions why the BUM Desa "Sejahtera" format is not fully capable of presenting an innovation ecosystem? The answer to that question can be traced from the history of the formation of BUM Desa in Bleberan. The initial formation of BUM Desa "Sejahtera" has not yet referred to the concept of hybrid institutions. Its history of formation is still driven by strong local initiatives initiated by the village government. Furthermore, these local initiatives are not articulated and adequately institutionalized in the rules of the game. Also, BUM Desa has also failed to adapt to the demands of the new spirit of the Village Law which mandates that BUM Desa is a village collective economy (between villagers and village government) that is managed democratically.

\section{Conclusion}

Based on the various findings, in sum: firstly, BUM Desa has potent to build an independent village economic institution as long as the principles as a hybrid institution are fulfilled. In the case of BUM Desa "Sejahtera" the format of the hybrid institution has not yet been fulfilled due to the weak capacity in institutionalizing the rules of the game that bind the perpetrators. The growth of local initiatives in Bleberan does not necessarily become a pillar of support for the growth of independent village economic institutions. It occurs because they are not matched by strong institutional capacities that drag the perpetrators into an unmanaged conflict of interest. The root of this weak institutional capacity occurred due to the absence of a system of integrity in the binding power relations system between the actors.

BUM Desa ideally can function as an incubator for villager innovation. In the case of BUM "Sejahtera" in Bleberan, in the beginning, a lot of innovations grew, but eventually, it was suspended because it was not properly captured and developed. In the context of the innovation ecosystem, the conclusions are based on findings as follow; Firstly, BUM Desa "Sejahtera" failed to bring accountable leadership. It is failed to apply public ethics and work ethics in the management of BUM Desa thus triggers the distrust of the villagers. Secondly, the cooperation of BUM Desa "Sejahtera" with various parties cannot be used to strengthen the capacity to revive the innovation ecosystem. Collaboration with innovation development institutions such as universities has not been able to stimulate innovation development. Thirdly, in collaborative funding, BUM Desa "Sejahtera" has not been able to optimize funding such as grants from the business institution or the government to develop an innovation climate. The funds obtained are used more to develop physical facilities and infrastructure, rather than to strengthen capacity. Fourthly, BUM Desa Sejahtera has not been able to foster a socio-cultural system and accommodate villager's initiatives. This resulted in weak innovation. Fifthly, BUM Desa "Sejahtera" does not encourage the growth of innovation or the use of various state regulations or programs that encourage innovation.

\section{References}


[1] A. Bebbington, L. Dharmawan, E. Fahmi, and S. Guggenheim, "Local Capacity, Village Governance, and the Political Economy of Rural Development in Indonesia," World Dev., vol.34, no.11. pp.1958-1976, (2006) DOI: 10.1016/j.worlddev.2005.11.025.

[2] M. Sofiyanto, R. M. Mardani, and M. G. Salim, "Pengelolaan Dana Desa Dalam Upaya Meningkatkan Pembangunan Di Desa Banyuates Kecamatan Banyuates Kabupaten Sampang,” J. Ris. Manaj., vol.6, no.04, (2017)

[3] F. Karimah, C. Saleh, and I. Wanusmawatie, "Pengelolaan Alokasi Dana Desa Dalam Pemberdayaan Masyarakat,” J. Adm. Publik, vol.2, no.4, pp.597-602, (2014)

[4] J. A. Seitz, “The Political Economy of Creativity," Creativity Research Journal. vol.15, no.4, pp.385-392, (2003) DOI: 10.1207/S15326934CRJ1504_6.

[5] D. Hastuti and N. Chilmy, "The Analysis of Local Potential in BUM Desa Empowering in Desa Lembengan, Kecamatan Ledokombo, East Java," J. Ilmu Sos. Mamangan, vol.6, no.2, pp.85-96, (2017) DOI: 10.22202/mamangan.2357.

[6] K. Cook, Social Capital: Theory and Research. Routledge, (2017)

[7] J. Dul et al., "A strategy for human factors/ergonomics: Developing the discipline and profession," Ergonomics, (2012) DOI: 10.1080/00140139.2012.661087.

[8] N. L. L. Aziz, “The Village Autonomy and The Effectiveness of Village Fund,” J. Polit., vol.13, no.2, pp.193211, (2016) DOI: 10.20885/unisia.vol27.iss53.art12.

[9] N. Azlina, A. Hasan, Desmiyawati, and I. Muda, "The effectiveness of village fund management (case study at villages in coastal areas in Riau),” Int. J. Econ. Res., vol.14, no.12, pp.325-336, (2017)

[10] T. Muntahanah and Siti. Murdijaningsih, "Efektifitas Pengelolaan Keuangan Alokasi Dana Desa Di Kecamatan Somagede Kabupaten Banyumas," Fak. Ekon. Univ. Wijayakusuma Purwokerto., vol 3, no.1, (2013)

[11] S. SI, "Social Media and Its Role in Marketing," Bus. Econ. J., (2015) DOI: 10.4172/2151-6219.1000203.

[12] W. J. Cosgrove and D. P. Loucks, "Water management: Current and future challenges and research directions," Water Resources Research. vol.51, no.6, pp.4823-4839, (2015) DOI: 10.1002/2014WR016869.

[13] M. R. R. S. Anggraeni, "Peranan Badan Usaha Milik Desa (Bumdes) Pada Kesejahteraan Masyarakat Pedesaan Studi Pada Bumdes Di Gunung Kidul, Yogyakarta,” MODUS, (2016) DOI: 10.24002/modus.v28i2.848.

[14] A. Payne, D. Ballantyne, and M. Christopher, "A stakeholder approach to relationship marketing strategy. The development and use of the 'six markets' model,” Eur. J. Mark., (2005) DOI: 10.1108/03090560510601806.

[15] M. Lisetchi and L. Brancu, "The Entrepreneurship Concept as a Subject of Social Innovation," Procedia - Soc. Behav. Sci., vol.124, no.0, pp.87-92, (2014) DOI: 10.1016/j.sbspro.2014.02.463.

[16] G. Hardin, “The tragedy of the commons," Science, (1968) DOI: 10.1126/science.162.3859.1243.

[17] E. Ostrom, "The challenge of common-pool resources," Environment, (2008) DOI: 10.3200/ENVT.50.4.8-21.

[18] L. German and A. Keeler, “'Hybrid institutions': Applications of common property theory beyond discrete tenure regimes,” Int. J. Commons, vol.4, no.1, (2009) DOI: 10.18352/ijc.108.

[19] S. Raudino and S. Raudino, "The Theory of Economic Development," in Development Aid and Sustainable Economic Growth in Africa, Cham: Springer International Publishing, (2016)

[20] OECD/Eurostat, Oslo Manual 2018: Guidelines for Collecting, Reporting and Using Data on Innovation (4th Edition), (2018)

[21] C. Moorman and G. S. Day, "Organizing for marketing excellence," in Journal of Marketing, vol.80, no.6, pp.635, (2016) DOI: 10.1509/jm.15.0423.

[22] P. Baxter, Susan Jack, and S. Jack, "Qualitative Case Study Methodology: Study Design and Implementation for Novice Researchers,” Qual. Rep, vol.,2008, DOI: 10.2174/1874434600802010058.

[23] S. B. Merriam, "Qualitative research: A guide to design and implementation, “ John Wiley \& Sons, (2009) 
Hybrid Institutionas An Enabling Factor of Innovation System: A Case Study of BUM Desa "Sejahtera” Bleberan Village, Gunung Kidul

This page is empty by intention. 